\title{
Jeremy Cohen A Historian in Exile: Solomon ibn Verga, Shevet Yehudah, and the Jewish-Christian Encounter
}

(Philadelphia: University of Pennsylvania Press, 2017), hardcover, viii + 248 pp.

\author{
REBECCA RIST \\ r.a.c.rist@ reading.ac.uk \\ University of Reading, Reading RG6 6AH, United Kingdom
}

This timely book explores crucial themes within the sixteenth-century Shevet Yehudah (The Scepter of Judah), a compilation of accounts of persecutions of the Jews by the Jewish writer Solomon ibn Verga and completed and edited by his son. Each chapter, divided into sub-headings, examines a theme in the context of late medieval Jewish-Christian relations. Chapters 1-5 draw on previous articles of Jeremy Cohen; the book contains three useful tables, endnotes and a bibliography.

In chapter one, "Religious Debate and Disputation," Cohen argues that Shevet Yehudah aims "to downplay the theological issues of the Jewish-Christian debate wherever possible" (p. 33). In chapter two, "Tortosa," he shows the work's purpose is not to analyze doctrinal issues but to display character interaction in order to highlight that for Judaism to survive, Jews must be able to deal with a sophisticated non-Jewish culture. It therefore "yields a picture reflecting Ibn Verga's own interests and agenda far more than what actually transpired at the Disputation in Tortosa in 1413-14" (p. 62). In chapter three, "Talmud and Talmudists," he argues the author ${ }^{1}$ deliberately focused "on the impact of the Talmud on the character and typical behaviors of the Jews," and was not just limited to refuting Christian polemics (p. 65). Further, he argues that the depiction of Talmudists must be understood within a long tradition of Christian criticism of halakhic scholars.

Cohen, in his fourth chapter "Anti-Jewish Libels," discusses the Shevet Yehudah's avoidance of the theological underpinnings of various libels historically

\footnotetext{
${ }^{1}$ Throughout this review I will refer to the author in the singular, although I recognize that determining authorship is difficult and there may well have been more than one author.
} 
aimed against Jews, concentrating instead on the depictions of characters who critique the charges. He argues in chapter five, "Martyrs and Martyrdom," that the author's "interest in martyrdom is considerably less than among other historical writers of his generation" (p. 128). Cohen also notes that although the author took liberties in representing fiction as history, he anchors his work in political and social realities. In chapter six, "Conversos and Conversion," he examines differences in the portrayal of forced and voluntary converts, which he sees as grounded in the author's own personal history. Cohen then critically assesses the nature of the Spanish "convivencia” (p. 147).

In chapter seven, "The Author and his Work: Purpose and Structure," Cohen explores tensions between natural and supernatural causation and between theological doctrine and practical relativism in the work. He analyzes the work's structure, focusing on its "Interior Signposts" and "Exterior Brackets" (pp. 16575) and the importance of Chapter Seven of the Shevet Yehudah to its overall meaning. He considers the work's postmodern flavour, the author's deliberate internalization of the viewpoint of a non-Jewish "Other," and his yearning for a post-polemical age of mutual appreciation. He also looks to Ibn Verga's context, including both the effect of early modern humanism on his thought and affinities to fifteenth-century writers Profiat Duran, Isaac Nathan, and Don Isaac Abravanel, who shared his cultural background and experiences.

Cohen seeks answers to pertinent questions about the Shevet Yehudah and the author's reasons for writing. He explores the tension between Jewish theological doctrine and the author's practical relativism. He convincingly argues that the author aimed to show the reason for the Jews' suffering throughout history and the complex nature of the opposition between Judaism and Christianity. He emphasizes the work's importance in the wider context of perennial questions about Jewish identity and the appropriateness of religious or racial categories.

Cohen provides sound insights into the author's appreciation of religiouslygrounded antagonism and his attempts to improve Jewish-Christian relations. He demonstrates his desire to keep on the right side of Christian rulers, along with his belief that secular powers such as kings and popes are agents of divine providence who often act better than other protagonists. He also shows that the author viewed attempts to convert Jews futile since they will remain true to their faith. We are presented with a convincing picture of an author relatively uninterested in historical accuracy, conservative, idealistic, critical yet witty, and determined to remain Jewish. His views can be difficult to determine since he appears to express his ideas through a mix of Jewish and Christian voices.

Another strength is the discussion of historiography. The works of distinguished scholars who have contributed to our understanding of Shevet Yehudah, such as Neuman, Dan, Schlüter, Funkenstein, Baer, Yassif, Ben-Shalom, Lasker, Schreckenberg, Limor, Yovel, Bonfil, Nirenberg, Gross, Katz, Fram, and Hacker, are all explored in relation to the book's main themes.

Cohen draws important conclusions about Shevet Yehudah: its uniqueness; its ambiguity; its internal criticism; its practicality; its complex structure; its lack of theology; its association with not just sixteenth- but fifteenth-century Jewish writ- 
ers; its aim "to entertain, edify, and delight" (p. 39); its message of hope over catastrophe; its view that Judaism depends not on theological instruction "but resides in Jews' conditioned nature as Jews" (p. 140); and its desire to understand Jewish history rationally and empirically. Three overriding elements give the work "programmatic unity" (p. 161): how to understand and react to Christian hatred of Jews, how to explain Jewish suffering, and how to determine religious boundaries between these two communities.

Cohen skilfully engages the research of many of the distinguished scholars who have written about the work. He also breaks new ground. Drawing on his earlier research on the Hebrew Crusade chronicles and ideas of Jewish martyrdom, he argues that the stories of suffering contained in Shevet Yehudah similarly draw on the collective trauma of Jewish communities. They are there in order to instruct and to empower contemporary Jews to build a better future. Cohen also draws on his earlier work on the friars, for example, when discussing the incendiary preaching of Vincent Ferrer (p. 36, p. 42, p. 58, pp. 61-2, p. 116).

There are weaknesses, particularly when discussing the medieval papacy. The interpretation of the legislation of Innocent III (p. 20) lacks nuance. Although it had the effect of oppressing Jewish communities, the pope's own correspondence reveals that it was not intended to cause Jews physical harm. Also potentially misleading is the statement that when a pope declared that the Jews' stubborn observance of the Law demonstrated their love for God, not hate, "the pope strays from the traditional teachings of the church" (p. 26), since PaulineAugustinian theology taught that, although the Jews erred in not accepting the Old Testament, they were still the people of the Old Covenant. The book occasionally lacks focus (e.g., the section "The Guardian of Israel never Sleeps" [pp. 103-16]), and sometimes gives the impression of having been hurriedly produced. A book of larger scope, which explored not just particular themes but the Shevet Yehudah as a whole would have been a valuable if enormous enterprise, and also would have resulted in a much longer book.

Nevertheless, Jeremy Cohen's book is an important addition to the field of Jewish-Christian relations. I look forward to the publication of the complete text, Solomon ibn Verga, The Scepter of Judah, trans. Yosef Hayim Yerushalmi, ed. Jeremy Cohen (in press). 